DOI No: http://dx.doi.org/10.29228/Joh.51059

Authenticity process is conducted by

Makale Türü: Araştırma makalesi

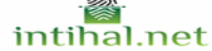

Geliş Tarihi: 25-04-2021

Kabul Tarihi: $15-07-2021$

On-line Yayın: 31-08-2021

Article Type: Research article Submitted: 25-04-2021

Accepted: 15-07-2021

Published Online: 31-08-2021

Attf Bilgisi / Reference Information

Day1, Ö. (2021). Moğol Asrında Basra Körfezi (1220-1335). Journal of History School, 53, 2370-2381.

\title{
MOĞOL ASRINDA BASRA KÖRFEZİ (1220-1335)
}

\section{Özkan DAYI ${ }^{1}$}

\section{$\ddot{\mathbf{O z}}$}

Moğolların İran coğrafyasına hâkim olması ile Güney İran bölgesinde bulunan yönetimlerin elinde bulunan Basra Körfezi'nin ticaret merkezleri de dolaylı olarak daha sonra İlhanlı Devleti'nin denetimine girmişti. Basra körfezi ticareti XIII. yüzyılda İlhanlı Devleti'nin önemli ticaret güzergâhlarından biri idi. Basra körfezi üzerinden yapılan ticaret, Umman ve Hind denizleri vasıtası ile baharat yolu ticarteinin önemli duraklarına ulamaktaydı. Basra körfezi vasıtası ile İlhanlılar, Arabistan, Hindistan, Çin ve Güneydoğu Asya diyarlarından getirilen kıymetli malları Avrupa'ya ulaştırmakta idiler. İlhanlılar zamanında oldukça zengin bir ticarî hayata sahip olan Basra körfezi, İlhanlı Devleti'nin iktisadî yapısının da önemli dayanaklarından birisi idi. Bu bağlamda Ortaçağ ticarî faaliyetlerinde değerli bir yeri olan Basra körfezi'ni ve bu körfezin komşu olduğu Umman ve Hind Denizi ticarî güzergâhını, bu bölgenin önemli ticaret limanlarını bu coğrafyada İlhanlı Devleti'nin hâkimiyeti sürecinde değerlendireceğiz. Basra körfezi civarında bulunan ve bu bölgenin ticaret limanlarını ellerinde bulunduran, İlhnalılara tabi yerel yönetimlerin İlhanlılar ile ilişkileri ve bu ilişkinin Basra körfezi ticaretne yansıması çalışmamızda ele alamaya gayret edeceğimiz bir diğre husus olacaktır.

Anahtar Kelimeler: Moğollar, İlhanlı Devleti, Basra Körfezi, Ticaret.

${ }^{1}$ Dr. Öğrt. Üyesi, Bayburt Üniversitesi İnsan ve Toplum Bilimleri Fakültesi Tarih Bölümü, Genel Türk Tarihi Anabilim Dalı, ozkandayi@bayburt.edu.tr, Orcid: 0000-0001-8192-3445 
Moğol Asrında Basra Körfezi (1220-1335)

\begin{abstract}
With the dominance of the Mongols in Iran, the trade centers of the Persian Gulf, which were in the hands of the governments in the Southern Iran region, came under the control of the Ilkhanate State indirectly. Persian Gulf trade was one of the important trade routes of the Ilkhanate State in the XIII. century. The trade over the Persian Gulf reached the important stops of the spice route trade through the Oman and Hind seas. Through the Persian Gulf, Ilkhanians were transporting precious goods, brought from Arabia, India, China and Southeast Asia to Europe. The Persian Gulf, which had a very rich commercial life in the age of the Ilkhanians, was also one of the important pillars of the economic structure of the Ilkhanate State. In this context, we will evaluate the Persian Gulf, which has a valuable place in the medieval commercial activities in this geography during the domination of the Ilkhanid State, and the trade route of Oman and the Indian Sea and the important trade ports of this region, which this gulf is adjacent to them. The relations of the local governments, which are located in the vicinity of the Persian Gulf and which are subject to the Ilkhanians, who are subject to the Ilkhanians, and the reflection of this relationship on the trade of the Persian Gulf, will be another issue that we will try to address in our study.
\end{abstract}

The Gulf of Persian in the Age of Mongol (1220-1335)

Keywords: Mongols, Ilkhanid State, Persian Gulf, Trade.

\title{
GíRiș
}

İran coğrafyasına tamamen hâkim olan devletler için tarih boyunca Basra Körfezi ticareti oldukça önemli olmuştur. XIII. yüzyılda bu coğrafyaya hâkim olan İlhanlılar, Basra Körfezi ticaretine de hâkim idiler. Bölgenin yer altı ve yer üstü zenginlikleir ile baharat yolu ticaretinin önemli bir merkezi olan Hindistan'a yakın oluşu ve bu ticaret güzergâhı üzerinde önemli ada ve limanlara sahip olması İlhnalı yönetimi için bu bölgeyi çok mühim bir konuma getirmekteydi.

Basra Körfezi’nin ticaret yolları için İbn-i Belhî ve İstahrî İlhanlı dönemi öncesi hakkında önemli bilgiler vermektedirler. İstahrî eserinde Basra Körfezi'nin meşhur limanlarından olan Sîrâf limanı vasıtası ile ticarî ilişkilerin yürütüldüğ̈̈ne değinmektedir (İstahrî, 1347 hş., s. 134). İbn-i Belhî ve Fazlullahi Şîrâzî Bölgenin ticaretinde XI. yüzyılda Fars bölgesinin limanları içerisinde Sîrâf limanının oldukça seçkin bir yeri olduğuna değinmektedir (Belhî, 1363 hş., 136; Şîrâzî, 1346 hş., 170). Selçuklular zamanında Basra Körfezi'ne kıyısı olan ve bu bölgede ticarî faaliyetlerde Kirmân ve Fars eyaletlerinin bir rekabet içerisinde olduğu bilinmektedir. Hürmüz'ün bir müddet Kirmân eyaletine bağlı bir ticaret merkezi olmuştu (İstahrî, 1347 hş., s.142). Ayrıca Basra Körfezi, İlhanlı zamanı yazarları tarafından el-Bahr yani deniz olarak nitelendirilmekteydi (Kâşânî, 1348 hş., s.170). 


\section{Özkan DAYI}

$\mathrm{Bu}$ doğrultuda bölgedeki mahallî yönetimlere İlhanlı Devleti'nin ihtimam gösterdiği bir gerçektir. İlhanlıların Çağatay ve Altın Orda devletleri ile sınır bölgelerinde çatışma halinde olması bu coğrafyalardaki ticarî hayatı da olumsuz etkilemekte idi. Ayrıca Anadolu ve Doğu Akdeniz ticareti de Memlûklarla yaşanan sıkıntılar yüzünden çok da emniyetli değildi. Tüm bu sebepler İlhanlı ülkesi için Basra Körfezi ve Karadeniz ticaretini oldukça önemli k1lmaktayd1.

İlhanlı Devleti'nin tesis edildiği dönemde Güney İran bölgesinde Fars bölgesinin Basra Körfezi kıyılarında, yine aynı bölge bulunan liman ve adalarda mahallî yönetimler hüküm sürmekteydi. Benî Kaysar Melikliği, Benî Tayyîbî, Hürmüz Emirliği ve Fars Atabekliği Basra Körfezi'nin ticarî ortamında iktisadî hayatlarını oluşturan yarı bağımsız sayabileceğimiz hanedanlar idiler. Bunların arasında Fars Atabekliği, Hürmüz Melikliği ve Kîş Adasında hüküm süren Benî Kaysar Emirliği önemli siyasî unsurlar idi. Ticarî zenginliği ve akışı devam ettirmek maksadı ile İlhanlılara tabi olan Basra Körfezi'nin mezkûr hanedanları İlhanlı ordularını metbû durumları ile Basra Körfezi ve Umman Denizi sahlinden ve limanlarından uzak tutmayı başarmışlardır (Spuler, 2011, s.165).

Basra Körfezi'ne bakan Güney İran sahillerine hâkim olan Fars Atabekliği, Kîş adasındaki Benî Kaysar Melikliği ve Umman Denizi'nin Basra Körfezi'ne bağlayan önemli bir boğaz üzerinde bulunan Hürmüz Melikliği bölgenin ticaretini ve siyasetine şekillendirmekte idiler. Çalışmamızda Basra Körfezi'nde İlhanlılar zamanında hüküm süren ve bu bölgenin ticarî hayatında etkili olan unsurları ele almayı hedeflemekteyiz. XIII. yüzyılda ticarî açıdan oldukça parlak bir dönem yaşayan Basra Körfezi'ndeki siyasî oluşumların ve ticarî hayatın ele alınmamış olması, bu konuyu ele almamızın ana sorununu teşkil etmektedir. $\mathrm{Bu}$ bağlamda bölgenin İlhanlı Devleti ile olan siyasî ve ticarî ilişkilerini, bölgede hüküm süren yerel yönetimlerin birbirleir ile olan çekişmelerini ve bölgenin ticarî hayatını dönemin kaynakları doğrultusunda değerlendirmeye çalışcağız.

\section{FARS ATABEKLIIĞI'NINN BASRA KÖRFEZI'NDEKİ FAALIYYTLERİ}

Moğol istilası İran coğrafyasını etkisi altına aldığı dönemde Fars bölgesine hâkim olan ve Güney İran'ın Basra Körfezi kıyılarını elinde bulunduran Salgurlular ya da diğer adıyla Fars Atabekliği, Moğollara tabi olmayı ve haraç vermeyi kabul ederek Basra Körfezi limanlarındaki ticarî hayatı korumayı başarmıştır. Böylece Atabek Ebû Bekr b. Sa'd b. Zengî, Moğolların himâyesine girmeyi kabul etmiş, kardeşini Ögedey Kaan'ın huzuruna göndermiş, Atabek Ebû Bekr b. Sa'd b. Zengî'nin bu davranışı üzerine Kaan, Atabek Ebû Bekr b. Sa'd b. 
Zengî’ye Kutluk Han unvanı ile bir yarlıg göndermiş ve ona Fars yönetimini bırakmıştı (Ebrû, 1375 hş., II, s.171). Fars Atabekliği'nin Moğollara tabi olması bölgeyi Moğol taarruzundan korumuştu (Mîrhând, 1380 hş., V, 3614). Ayrıca Şebânkâre bölgesinin Atabeği olan Melik Kutbeddîn Mubârezeddîn Muzafferuddîn Muhammed, altın bin dinar karşılığında Şebânkâre mıntıkasını Hülegü'den mukataa olarak almıştı (Natanzî, 1336 hş., s.11; Şebânkâreî, 1343 hş., s. 156-158).

Çalışmamızın konusunu teşkil eden Basra Körfezi'nin sahil bölgesine hâkim olan devletlerden biri merkezi Şîrâz olan Salgurlular adı ile de bilinen Fars Atabekliği, Atabek Zengî b. Mevdûd zamanında kurulmuştu (Şebânkâreî, 1343 hş., s.182-183). Atabek Muzafferuddîn Ebû Bekr b. Sa'd Salgur (1235-1259) zamanında bu bölgede parlak bir ticarî hayat yaşanmıştı, Atabek Muzafferuddîn Ebû Bekr b. Sa'd Salgur, 1230 tarihinde Güney İran sahillerinde bir askerî harekât başlatmıştı. Bu harekât sonunda Umman Denizi'nin sahil bölgesi, Kîş, Ummânât, Bahreyn ve Katîf gibi Basra Körfezi'nin Arabistan sahilinde yer alan birçok yeri ele geçirmişti (Şîrâzî, 1346 hş., s. 179; Zerkûb-i Şîrâzî, ty., s.80). Atabek Muzafferuddîn Ebû Bekr b. Sa'd Salgur'un bu faaliyetleri üzerine ona "Sultânu'lBerri ve'l-Bahri” yani karalaraın ve denizlerin sultanı unvanını almıştır (Şîrâzî, 1346 hş., s.178; Merçil, 1991, s. 98). Böylece Fars bölgesi ve bu bölgenin kıyıları Salgurlular zamanında hem ticarî açıdan hem de siyasî açıdan oldukça parlak bir dönem yaşamıştır. Ayrıca bu dönemde Hindistan'ın Kenbâyet hâkimi, Fars Atabekliği'ne tabii olmuştı (Şîrâzî, 1346 hş., s.178).

Daha sonra İlhan Hülegü'nün oğlu Mengü Timur, Sa'd b. Ebîbekr b. Sa'd'ın kızı Âbiş Hatun ile ile evlenince resmen Fars atabekliği Moğollara bağlı uydu bir devlet haline gelmiş oldu (Şebânkâreî, 1376 hş., s. 198-199). Atabek Ebû Bekr zamanında, Salgurluların Basra Körfezi'nde yürüttükleri arkerî harekâtta Bahreyn bölgesi de ele geçirilmişti (Şebânkâreî, 1376 hş., s.184).

Fars bölgesi tâcirlerinin Hindistan coğrafyasının hâkimleir ile de görüștüklerini Târîh-i Vassâf'tan öğrenmekteyiz. Ticaret yapmak amacı ile Hindistan'da hükümdarlar ile görüşen Fars bölgesinin tâcirleri, oldukça hükümdarlar tarafından Hind sarayında hürmet görmekte idiler (Şîrâzî, 1346 hş., s. 171).

\section{BENÎ KAYSAR HANEDÂNI'NIN BASRA KÖRFEZI'NDEKİ FAALIYYTLERİ}

Basra Körfezi'ndeki bir diğer yerel hanedân ise Benî Kaysar Emîrliği idi. Benî Kaysar ailesi önceleri Sîrâf limanında ticaret ile meşgul iken daha sonra Kîş 


\section{Özkan DAYI}

adasına göç etmişler ve burada ticarete başlamışlardır. Benî Kaysar ailesi Kirmân Selçukluları ve Fars Atabekliği'ne tabii bir şekilde yaşamışlar ve bu hükümetler adına Basra Körfezi'nde vergi toplamışlardır. Atabek Sungur, Benî Kaysar ailesine Basra Körfezi’nde kısmı yönetim serbestliği tanımış, bu durum sonucunda Basra Körfezi'nin batı sahilllerinde bu aile oldukça güçlenmişti (İkbâl 1328 hş., s.32).

Fars Atabekliği’ne tabii olan Benî Kaysar aileis, Melik Cemşîd zamanında Salgurlular ile uyumlu politikalarını terk ettikleri için Atabek Ebû Bekr'in tepkisini çekmekteydiler. Bu durum üzerine Hürmüz Adası'nın meliki Seyefeddîn Ebû Nasr, Atabek'e yardımcı olmak ve Kîş Adası'nı ele geçirmek için Salgurlulara ittifak teklif etmişti. Bu teklif Atabek Ebû Bekr tarafindan kabul edilmişti (Şîrâzî, 1346 hş., s. 175-176). Benî Kaysar ailesinin Basra Körfezi'ndeki yönetimine, Atabek Ebu Bekr Salgurî'nin müttefiki ve komutanı Seffeddîn Ebû Nasr Hürmüzî tarafından 1228 tarihinde son verilmiştir. Kîş adası daha sonra 1230 tarihinde doğrudan Fars Atabekliğine bağlanmıştı (Şîrâzî, 1346 hş., s. 176-178).

İlhanlılar zamanında Kîş Adası'nı ellerinde bulunduran Benî Kaysar ailesi, inci avcılığından ve inci ticaretinde de oldukça servet edinmekteydiler. Çünkü Basra Körfezi'nde yaygın olan incilerin en kıymetlileri Kîş Adası civarından çıkarılmakta ve başka hiçbir yerde bulunmayan büyük inciler bu mıntıkadan çıkarılmakta idi. (Müstevfî, 1342 hş., s.343).

\section{HÜRMÜZ MELİKLERI'NİN BASRA KÖRFEZI'NDEKİ FAALIYYETLERİ}

Moğolların İran'a hâkim olduğu XIII. yüzyılda, Basra Körfezi'nin önemli siyasî güçlerinden biri de Hürmüz Melikliği idi. Bu devlet, Muhammed Deremkûb tarafından kurulmuştu. Hürmüz Boğazı ve civarını ele geçiren Muhammed Deremkûb, kendi adına para bastırmış, Fars Atabekliği ve Kirmân Selçuklulkarı ile iyi ilişkiler kurmaya çalışmıştır. Benî Kaysar ailesine karşı Salgurlular ile müttefik olan Hürmüz Meliği Seyfeddîn Nasr, Kîş Adası'nı ele geçirdikten sonra Atabek Ebû Bekr ile yaptığı anlaşmalara uymaması üzerine Atabek, Fars kıyılarında bulunan Hürmüz Meliği'ne ait olan limanları ele geçirmiş, ayrıca daha önece Benî Kaysar'a tabi olan gemi sahibi tacirlerden Seyfeddîn Nasr'a karşı da ittifak teklifi almıştı (Şîrâzî, 1346 hş., s. 177-178). Atabek Ebû Bekr, mezkûr tacirlerden aldığı donanma desteğine ek olarak bir ordu da teşkil etmişti. Kîş Adası'nda 1230 tarihinde yapılan savaşta Seyfeddîn Nasr, yenilmiş ve katledilmişti. Böylece daha sonra İlhanlılara tabii olan Fars 
Atabekliği'nin Basra Körfezi’ndeki hâkimiyet alanı genişlemişti (Şîrâzî, 1346 hş., s. 178).

Moğolların İran'a saldırılarının başladığı dönemde Cihânşâh, Hürmüz yönetiminin başında idi. Fakat kendisi Güney İran'da Moğollar ile mücadele ederken öldürülmüş, yerine ise Mîr Şehâbeddîn geçmişti. Rukneddîn Mahmûd zamanında Hürmüz Emirliği, Maskat bölgesini de kendi egemenliklerine almıştı. Rukneddîn Mahmûd, Suncak Noyan'ın² Fars bölgesindeki hâkimiyeti zamanında Kîş Adası'na da hükrân olmak istemiş, fakat Suncak Noyan'ın askerî harekâtı ile yenilmiş ve Hürmüz mıntıkasına doğru çekilmişti. Rukneddîn Mahmûd'un vefatından sonra oğlu Emîr Seyfeddîn Nusret, Hürmüz hâkimi olmuş fakat şehzâdeler arasındaki çatışmalar yüzünden 1290 tarihinde Hürmüz iktisadî açıdan oldukça zarar görmüştü (Şîrâzî, 1346 hş., s. 296).

$\mathrm{Bu}$ çatışma dönemine hanedana mensup Ayâz son vermiş, Moğolların bu bölgeye olan akınlarını engellemişti (Şîrâzî, 1269 hş., s. 297). Ayâz'ın 1311 tarihine kadar süren hâkimiyetinde Hürmüz, yeniden ticarî bir merkez olma özelliğini kazanmıştı. Ayâz'dan sonra Rukneddîn Mahmûd'un torunu Rukneddîn Mes'ûd'un oğlu İzzeddîn Kerdânşâh, Hürmüz hükümetinin başına geçmiştir (Kâşânî, 1348 hş., s.154-156). O, hâkimiyet mücadelelerinden sonra Hürmüz yönetimini tamamen ele geçirmiş, 1344 yllına gelindiğinde egemenliğini Kîş, Bahreyn ve Basra Körfezi’nin önemli bir kısmına yaymıştı. İlhanlı Devleti’nin son zamanlarında Hürmüz Melikliği üzerindeki İlhanlı siyasî baskısının azalması ile Basra Körfezi'nin ticaretini ele geçirmişti. Rukneddîn Mahmûd b. Ahmed Kalhâkî, Emîr Bahaeddîn Ayâz ve Kutbeddîn zamanlarında Hürmüz Emirliği, İran'ın merkezî yapısından ve İlhanlı baskısından uzak olmanın vermiş olduğu rahat bir ortamda iktisadî olarak oldukça gelişim göstermiş̧t (Natanzî, 1336 hş., 17-20).

\section{TAYYÎBÎ HANEDÂNI'NIN BASRA KÖRFEZI'NDEKİ FAALIYETLERI}

Kîş Adası, bölge ticaretinde önemli bir yere sahip idi. Bu mühim merkezleri elinde bulunduran hanedânların yanında yine bazı küçük mıntıkalarda hâkim olan unsurlar bulunmakatydı. Bu hâkim unsurlardan biri de Tayyîbî hanedânı idi, Sa‘dî-yi Şîrâzî’nin verdiği bilgilere göre, Tayyîbî hanedanı, büyük ticaret kervanlarına sahip olup, oldukça zengin bir aile olarak Fars eyaletinin kıyı bölgesinde faaliyet göstermekte ve bu ailenin büyük deve sürüleri, birçok

\footnotetext{
${ }^{2}$ Suncak Noyan hakkında bkz. (Şî̂â̂zî, 1346 hş., s.32; Beyzâvî, 1382 hş., s.133; Âştiyânî, 1374 hş., s.200-201; Rezevî, 1354hş., s.151; Yuval1, 1994, s.132).
}

[2375] 


\section{Özkan DAYI}

çalışanları mevcut olup ticarî ve siyasî açıdan bölgedeki diğer hanedanların gölgesinde bulunduklarını anlamaktayız (Sa'dî, 1374 hş., s.100).

İlhanlılar zamanında Fars Atabekliği’ne tabii olan Tayyîbî ailesinin lideri bu dönemde Melik İslâm Cemâleddîn Tayyîbî idi. Melik İslâm Tayyîbî zamanında Fars bölgesinde önemli bir ticarî yere sahip olan Tayyîbî aileisi, iyi cins at ticaretinden oldukça servet sahibi olmuşlardı. Fars bölgesinde yetiştirilen bu iyi cins atlar, Tayyîbî ailesi vasıtası ile deniz ticareti vasıtası ile Hindistan'a yüksek meblağlarda satılmaktaydı.bu ticaret Kîş Adası güzergahı ile yapılmaktaydı (Âyetî, 1372 hş., s.172; Zerkûb-i Şîrâzî, 99-111). Her at iki yüz yirmi altın dinara satılmakataydı. Târîh-i Vassâf'a göre, Atabek Ebû Bekr zamanında her yıl satılan atların sayısı on bini bulmaktaydı (Şîrâzî, 1346 hş., s.302). Tayyîbî ailesi, Fars bölgesi ve Hindistan arasındaki iyi cins at ticaretini yapmaktaydı. Tayyîbî hanedanının vezâret işleri ile de Melik İslâm Cemâleddîn Tayyîbî'nin kardeşi Meliku'l-A'zam Merzbânu'l-Hind Takîyuddîn Abdurrahmân b. Muhammed Tayyîbî ilgilenmekteydi (Şîrâzî, 1346 hş., s. 303).

İlhanlılar zamanında Melik İslâm, Basra Körfezi'nde hâkim olan diğer güçler ile bir mücadele içerisinde idi. Hürmüz Melikleri, Tayyîbî ailesinin en büyük rakibi olup, Hürmüz bölgesindeki korsanlar ile mücadele etmekteydiler (Şîrâzî, 1346 hş., s. 297). Tayyîbî hanedanından olan İzzeddîn Abdulazîz, 1324 tarihine kadar Basra Körfezi’nde ticarete ve inci avcılığı faaliyetine hâkim idi. İzzeddîn Abdulazîz, Hürmüz ve civar bölgelere ayrıca askerî harekât da düzenliyordu (Kâşânî, 1348 hş., s.162-163).

\section{5. İLHANLILAR ZAMANINDA BASRA KÖRFEZI'NDEKİ LIMANLAR VE TICARÎ HAYAT}

İlhanlıların İran'a hâkim oldukları dönemde Basra Körfezi’ndeki yerleşim alanlarının ve limanların parlak bir çağ yaşadığını söyleyebiliriz. Bu dönem bölgede hüküm süren yerel hanedanların ticarî çabaları ile gerçekleşmişti. Bu hanedanların elinde bulunan Hürmüz ve Kîş Adası gibi siyasî işlevi de olan büyük ticaret merkezlerinin dışında önemli limanlar da mevcut idi. İlhanlı asrının önemli bir kaynak eseri olan Hamdullah Müstevfî-yi Kazvînî'nin Nuzhetu'lKulûb adlı eseri doğrulturunda bu liman şehirlerini tanıtacağı.

Sîrâf, kadim ve bereketli bir şehir olarak Müstevfî tarafından tanıtılmaktadır (Müstevfî, 1342hş., s. 117). Sîrâf, tâcirlerin ve kaptanların firtınalı zamanlarda bir sığınağı idi. Rîşehr (Bûşehr) limanı, bir ticaret merkezi olmasının yanında, Rîşehr'in etrafında hurma ve keten tarımı da yapılmaktaydı (Müstevfî, 1342 hş., s.130). Sînîz (Şînîz) limanı, Basra Körfezi’nin kuzey batısında yer 
almakta, bu limanda yüzlerce gemi ve kayık demirlemekteydi. Sînîz bölgesinin halkı deniz ticâreti ile meşgul idi. Müstevfî’ye göre bu bölgede keten dokumacılığ ve aydınlatmada kullanılan keten yağı üretimi de yapılmakta idi (Müstevfî, 1342 hş., s.131). Hürmüz'e yakın bir konumda olan Kaşm, tatlı su kaynakları ile Basra Körfezi’nin önemli limanlarından idi (Müstevfî, 1342 hş., s.137).

Hind Denizi'ne yakın sahillerde yani güney doğu İran sahillerinde XIII. yüzyıl boyunca önemli limanlar bulunmaktaydı. Kirmân coğrafyasının güney doğusunda yer alan Mekrân, oldukça geniş bir bölge olup, bu mıntıkanın uzun bir sahil şeridi bulunmaktaydı. Hamdullah Müstevfî'ye göre, Mekrân İran coğrafyasının dışında bulunmasına rağmen İlhanlı yönetimine haraç verdiği için İlhanlı ülkesinin bir parçası olan Kirmân'a dâhil idi (Müstevfî, 1342 hş., s.141).

Basra Körfezi'nin en kuzey ucunda bulunan Basra şehrinin limanı Basra Körfezi'nin en önemli birkaç limanından biri idi. Zira Irak coğrafyasına deniz tarikinden bu liman vasıtası ile giriş yapılabiliyordu. Hind, Çin, Arap ve Afrika diyatlarından getirilen değerli mallar, Basra bölgesinden denize dökülen Şattu'lArab mıntıkası üzerinden Dicle nehrine ulaştırılıyor, bu nehir vasıtası ile gemiler Irak içlerine kadar ticaret malları taşıyabiliyorlardı (Müstevfî, 1342 hş., s. 38).

Marco Polo seyahatnamesinde bu dönemde Bağdad'da, Basra körfezi civarında üretim yapan merkezlerin ya da atölyelerin var olduğu ve Basra bölgesinden Dicle nehri vasıtası ile malların Bağdad'da taşındığı, Hindistan'dan getirilen incilerin Bağdad üzerinden Avrupa'ya tacirler tarafindan götürüldüğü Marco Polo tarafından zikredilmektedir (Polo, 2003, s. 74). Ayrıca bu dönemde kara ticaret yolu Tebriz-Erzurum-Trabzon istikâmeti üzerinden Karadeniz ticarî güzergâhına bağlanmışı (Ciociltan, 2012, s. 35-36). Deniz ticareti bu dönemde oldukça önem arz etmekte olup Basra körfezi üzerinden Hindistan ve Uzak Doğu ile yapılan ticaret İlhanlı ülkesinin en canlı ticaret hattını oluşturmakta idi (Petroşevsky, 1366 hş., s. 38).

Tûn ve Kâin şehirlerinde yetiştirilen kıymetli atların Kîş ve Hürmüz üzerinden yani Basra körfezi üzerinden deniz yolu vasitası ile Hindistan'a götürüldüğ̈̈, ticaret yollarının güvenliği meselesinin Moğol idareciler tarafindan sağlandığ 1 yine Polo tarafından belirtilmektedir (Polo, 2003, s. 44). Basra Körfezi'nde Hürmüz boğazına yakın bir konumda bulunan Kîş adasının limanı İlhanlılar zamanında önemli bir ticaret durağı olup, Hintli, İranlı ve Arap tacirlerin buluşma noktası halindeydi (Kazvînî, 1366 hş., s. 53).

Argun zamanında Cenevizlilar Irak'ın kuzeyinde Dicle üzerinden Basra Körfezi'ne ve Hind denizine kadar uzanan sahada ticaret yapmak için gemiler 
yapmaya başlamışlardı (Cevâdî, 1378 hş., s.101). Argun döneminde Basra körfezi ve Hind denizi ticareti oldukça işlek bir ticarî saha idi. Ticaretin bu parlak döneminde, Kirmân ve Fars bölgelerinin limanları üzerinden başlayan bu ticaret yolu Hindistan sahilindeki limanlara kadar uzanmaktaydı (Rezevî, 1388 hş., s. 242).

Gâzan Han öncesinde parlak bir dönem yaşayan Basra körfezi ticareti, Gâzân zamanında da gelişim göstermiş hatta Cemâleddîn İbrahim Tayyibî gibi İlhanlı devlet adamları Basra körfezi ticareti ile meşgul olmuşlar ve önemli servete ve güce ulaşmışlardır. Cemâleddîn İbrahim Tayyibî, on yıl boyunca Basra körfezini mukataa olarak elinde tutmuş ve Gâzân Han'ın huzuruna geldiğine hana; bin at, kıymetli çeşitli inciler, altın işlemeli elbiseler, çeşitli mücevherler, Hindistan ve Çin ülkelerinde imal edilen altın ve gümüş eşyalar takdim etmiştir (Şîrâzî, 1346 hş., s. 331). Bu durum bize Gâzân Han zamanında Hindistan ve Çin ülkeleri ile yapılan ticaretin ne kadar yaygın olduğunu göstermektedir. Gâzân Han'ın aldığı tedbirler ve yaptığı reformlar sayesinde İlhanlı ülkesinde ticaretin parlak bir dönem yaşadığını, bir düzene kavuştuğunu ve ülkenin iktisadî yapısının toparlanma gösterdiğini söyleyebiliriz. (Cevâdî, 1378 hş., s. 103-106). Nuzhet'ulKulûb'un yazarı Müstevfí; Basra hurmasının Çin ve Hindistan'a, Isfahan meyvelerinin Hindistan ve Anadolu'ya ticarî mal olarak taşındığından bahsetmektedir. (Rezevî, 1388 hş., s. 269-270).

$\mathrm{Bu}$ Bölgede ticaretin yürütüldüğ̈̈ önemli limanlar ve adalar mevcut idi Bunlara Kaşm, Sîrâf, Rîşehr, Hârek, Cenâbe, Sînîz, Mehrûbân, Ma'şûr, Abâdân ve Kîş örnek olarak verilebilir (Müstevfî, 1342 hş., 130-138). Bu limanların içerisinde Kîş önemli bir yere sahip olup Çin ve Hind diyarları gibi farklı ülkelerden gelen tâcirler buraya çeşitli ipek, keten ve farklı hububatları bu adaya getirirler ve bu üürnlerin mukabilinde inci satın alırlardı. Ayrıca bu adada hurma bahçeleri bulunmakta idi. Kîş adasının evleri ise birkaç katlı idi. Kîş adası gibi Hürmüz adası da dönemin önemli ticarî duraklarından idi. Dört yüzden fazla Asyalı büyük tâcir bu adada ikamet eder, inci, ipek, halı, baharat, değerli taşlar ve iyi cins İran atları üzerinden ticaret yaparlardı (Nûrîzâde Bûşehrî, s.101, 111112). Hâfız Ebrû eserinde Hürmüz Adası'nın bir deniz ticareti merkezi oladuğuna dikkar çekmiş ve bu ada civarında inci yataklarının oldukça çok fazlalığına değinmiştir (Ebrû, 1375 hş., III, s.16).

\section{SONUÇ}

İlhanlı Devleti'nin Ön Asya coğrafyasında etkin bir siyaset yürüttüğü dönemde Basra Körfezi ticareti, İlhanlı ülkesinin İktisadî yapısında önemli bir 
yere sahipti. İlhanlıların Altın Orda, Çağatay ve Memlûk devletleri ile yaşadığı siyasî ve askerî sıkıntılar Hürmüz bölgesinden başlayıp Karadeniz sahillerine kadar uzanan güney-kuzey güzergâhında ticaretin oldukça gelişmesine sebep olmuştu. Bu ticarî yapının temel dayanağını ise, Basra Körfezi’ne Güney Asya'dan gelen kıymetli ticarî mallar oluşturmakta idi. Bu kıymetli ticarî ürünler, deniz yolu ile Basra'ya daha sonra Dicle nehri vasıtası ile Bağdad'a kadar gemiler ile taşınmaktaydı. Bağdad'a gelen bu ticarî ürünler Tebriz-Erzurum hattı üzerinden Karadeniz limanlarına ulaşmakta ve Cenevizli tâcirler vesile ile Avrupa'ya ulaşmaktaydı.

$\mathrm{Bu}$ zengin ticaretin başlangıç noktasını oluşturan Basra Körfezi'nde İlhanlıların metbûsu Fars Atabekliği'ne tabii yerel hanedanlar bulunmaktaydı. Hürmüz ve Kîş Adası'nda hüküm süren Benî Kaysar ve Benî Tayyîbî hanedanları, dolaylı olarak İlhanlı Devleti'ne bağlı idiler. Fars Atabekliği'nin İlhanlı merkezî yönetimi ile en başından beri uyumlu bir siyasî çizgide olması, aynı zamanda Basra Körfezi'nde Fars Atabekliği'ne tabii bu yerel hanedanların da siyasî ve ticarî açıdan Moğol baskısından korunmalarına sebep olmuştur. $\mathrm{Bu}$ durum beraberinde Moğol istilasını ve sonuçlarını oldukça ağır yaşayan Ön Asya'nın siyasî ve iktisadî vaziyetinin Basra Körfezi ticaretine yansımamasına sebep olmuştur. Fars Atabekliği'nin İlhanlılar ile uyumlu siyaseti sadece sanatsal ve kültürel açıdan Fars bölgesini korumamış, aynı zamanda Fars Atabekliği'ne bağlı yerel hanedanları da himaye etmiştir.

İlhanlılar zamanında bölgenin zengin ticarî yapısının bozulmaması Basra Körfezi'nde mevcut olan yerel hanedanların menfaatine olmuş ve bu hanedanlar zaman zaman Fars Atabekliği'nin de zayıflaması ile kendi aralarında Basra Körfezi hâkimiyeti için mücadele etmişlerdir. Sonuç olarak, Basra Körfezi'nin İlhanlı Devleti zamanında ticarî açıdan oldukça parlak bir dönem yaşadığını ve bu bölge vasıtası ile İlhanlı ülkesinin ticarî hayatı oldukça gelişmiştir. Bölgedeki Benî Kaysar, Benî Tayyîbî ve Fars Atabekliği'nin siyasî ve ticarî faaliyetlerinin çalışmamız ile ele alınması, İlhanlı Devleti'nin ticarî hayatını daha iyi anlaşılmasını sağlayacağı kanaatindeyiz.

\section{KAYNAKÇA / REFERENCES}

Âştiyânî, A. İ. (1374 hş.). Târîh-i Mogûl ve Evâyil-i Eyyâm-i Teymûrî. İntişârât-i Nâmek.

Beyzâvî, Ö. (1382 hş.). Nizâmu't-Tevârîh (Tsh. Mîr Hâşim Muhaddes).

Cevâdî, H. (1378 hş.). Irrân ez Dîde-i Seyyâhân-i Arûpâî. İntişârât-i Bûte. 


\section{Özkan DAYI}

Ciociltan, V. (2012). The Mongols and the Black Sea Trade in the Thirteenth and Fourteenth Centuries. Brill Publising.

Ebrû, H. (1375 hş.). Cogrâfyâ-yi Târîh-i Hâfiz Ebrû (Tsh. Sâdık Seccâdî). Defteri Neşr-i Mîrâs-i Mektûb.

İbn-i Belhî. (1363 hş.). Fârsnâme. İntişârât-i Donyâ-yi Kitâb.

İkbâl, A. (1328 hş.). Mutâla 'âtî der Bâb-i Bahreyn ve Cezâyir ve Sevâhil-i Hakîci Fârs. Çâphâne-i Meclis.

İstahrî, E. İ. (1347 hş.). Mesâlik ve Memâlik (Tsh. İrec Efşâr). Neşr-i Kitâb.

Kâşânî, E. K. (1348 hş.). Târîh-i Olcâytû (Tsh. Mîhen Hanbelî). Neşr-i Kitâb.

Kazvînî, H. M. (1342 hş.). Nuzhetu'ul-Kulûb (Tsh. G. Le Strange). Donyâ Kitâb.

Kazvînî, Z. M. (1366 hş.). Âsâru'l-Bilâd ve Ahbâru'l 'İbâd. Emîr Kebîr.

Merçil, E. (1991). Fars Atabekleri Salgurlular. Türk Tarih Kurumu.

Natanzî, M. (1336 hş.). Muntehibu't-Tevârîh-i Mu înî (Tsh, Jean Uben). Esâtîr.

Nûrzâde, B. İ. (ty), Nazar-i be Îrân ve Halîc-i Fârs.

Petroşevsky, I. P. (1366 hş.). Târîh-i İctimâ̂-İktisâdî-yi der Dover-i Mogûl. İntişârât-i İtlâ'ât.

Polo, M. (2003). Marco Polo Dünya'nın Hikâye Edilişi. Ötüken.

Rezevî, M. T. M. (1354 hş.). Ahvâl ve Âsâr. İntişârât-i Bunyâd-i Îrân.

Rezevî, S. E. (1388 hş.). Şehr, Siyâset ve İktsâd der 'Ahd-i Îlhânân. İntişârât-i Emîr Kebîr.

Spuler, B. (2011). Iran Moğollart. Türk Tarih Kurumu.

Şebânkâreî, M. A. (1343 hş.). Mecma 'u’l-Ensâb (Tsh. Mîr Hâşim Muhammed). İntişârât-i Emîr Kebîr.

Şîrâzî, S. (1374 hş.). Kulliyât-i Sa 'dî (Tsh. Muhammed Furûgî). İntişârât-i Rehâ.

Şîrâzî, Ş. F. (1346 hş.). Tahrîr-i Târîh-i Vassâf (Tsh. Abdulmuhammed Âyetî). İntişârât-1 Bonyâd-1 Ferheng-i Îrân.

Yuvalı, A. (1994.). Ilhanlılar Tarihi I Kuruluş Devri. Erciyes Üniversitesi Matbaas1.

Zerkûb-i Şîrâzî. M. (ty.). Şîrâznâme (Tsh. İsmâ'îl Vâ'iz Cevâdî). Bonyâd-i Ferheng-i İrân. 


\section{EXTENDED ABSTRACT}

The Persian Gulf trade had an important place in the economic structure of the Ilhanli country during the period when the Ilkhanate State was conducting an effective policy in the Asia Minor. Political and military troubles experienced by the Ilkhanians with the Golden Horde, Chagatay and Mamluk states led to the development of trade on the south-north route starting from the Hormuz region and extending to the Black Sea coast. The main pillar of this commercial structure was precious commercial goods coming from South Asia to the Persian Gulf. These precious commercial products were transported by sea to Basra and then to Baghdad via the Tigris river by ships. These commercial products coming to Baghdad reached the Black Sea ports via the Tabriz-Erzurum line and reached Europe by means of Genoese traders.

In the Persian Gulf, which was the starting point of this rich trade, there were local dynasties subject to the Persian Atabeklik, the capital of the Ilkhanians. The Bani Kaysar and Bani Tayyîbî dynasties, who ruled in Hormuz and Kish Island, were indirectly affiliated with the Ilkhanid State. The fact that the Persian Atabeklik has been in a political line in harmony with the Ilkhanid central administration from the very beginning has also led to the protection of these local dynasties, which are subject to Persian Atabekism in the Persian Gulf, from Mongol oppression in political and commercial terms. This situation, along with the Mongol invasion and its consequences, caused the political and economic situation of the Front Asia not to be reflected in the Persian Gulf trade. The politics of the Persian Atabeklik in harmony with the Ilkhanians not only protected the Persian region in artistic and cultural terms, but also protected the local dynasties affiliated to the Persian Atabeklik.

In the time of the Ilkhanians, the preservation of the rich commercial structure of the region was in the interest of the local dynasties in the Persian Gulf and these dynasties struggled for the dominance of the Persian Gulf from time to time with the weakening of the Persian Atabeklik. As a result, the Persian Gulf had a very bright period in terms of trade during the Ilkhanid State and the commercial life of the Ilhanli country was quite developed through this region. We are of the opinion that addressing the political and commercial activities of the Bani Kaysar, Bani Tayyîbî and Persian Atabekliği in the region with our work will provide a better understanding of the commercial life of the Ilkhanid State. 